\title{
BLOOD COAGULATION PROBLEMS IN OPEN-HEART SURGERY*
}

\author{
BY \\ P. FANTL AND H. A. WARD \\ From the Baker Medical Research Institute, Alfred Hospital, Melbourne
}

(RECEIVED FOR PUBLICATION JULY 9, 1960)

For operation on the blood-free exposed heart large volumes of heparinized blood are required and the restoration of normal blood coagulation soon after the operation is completed is important. Over the past three years we have assisted thoracic surgeons in problems connected with blood coagulation in open-heart surgery, both with regard to the haemostasis of the patient before and after bypass and also in the preparation of donor blood required for the extracorporeal circulation. The experience gained is given in this report, which covers 50 cases. They include ventricular septal defects, Fallot's tetralogy, complicated forms of atrial septal defects, and complicated forms of pulmonary stenosis.

The haemostatic mechanism of all patients was examined pre-operatively. This seemed desirable because many of the patients were of the younger age groups and might suffer from previously unnoticed haemorrhagic tendencies. These tendencies may introduce difficulties in the postoperative period which, however, can be dealt with specifically.

\section{METHODS}

In order to assess the patient's haemostasis a number of tests were carried out. Techniques for the blood coagulation tests are given by Fantl (1954) and Fantl and Ward (1960).

Determination of Heparin.-For the present work it was essential to determine blood heparin concentration in a very short time so that the proper concentration could be maintained during the operation with as little delay as possible. Postoperatively it was equally urgent to control the removal of heparin from the circulation.

The following procedure for heparin assay was adopted. Before the operation the relationship between heparin concentration and thrombin clotting time was established. To $0.2 \mathrm{ml}$. fresh normal human oxalated plasma in clotting tubes was added $0.05 \mathrm{ml}$.

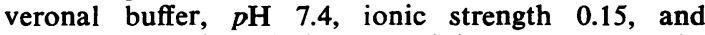
$0.05 \mathrm{ml}$. heparin solution containing 0.01-0.03 units

\footnotetext{
*This project was carried out with the aid of a grant from the National Health and Medical Research Council of Australia.
}

(u.) of heparin in $0.154 \mathrm{M}$ sodium chloride $(\mathrm{NaCl})$. Into the mixture, which was kept in a water-bath at $37^{\circ} \mathrm{C}$. for at least $1 \mathrm{~min}$., was blown $0.1 \mathrm{ml}$. of a thrombin preparation (kept at $2^{\circ}$ C.), and the clotting time determined. In the absence of heparin it should be $15.0 \pm 0.5$ sec. A graph was drawn relating heparin concentration and thrombin clotting time. Between 0.01 and $0.02 \mathrm{u}$. heparin in $0.05 \mathrm{ml}$. give clotting times between 20 and $35 \mathrm{sec}$. Such determinations have to be carried out on each working day, because of variations in the reactivity of the reagents. For the heparin assay $9 \mathrm{ml}$. blood was mixed with $1 \mathrm{ml}$. $0.1 \mathrm{M}$ sodium oxalate and $0.05 \mathrm{ml}$. of this mixture was used in the above test instead of $0.154 \mathrm{M} \mathrm{NaCl}$. If the clotting time was greater than 35 sec. blood was diluted with $0.154 \mathrm{M} \mathrm{NaCl}$ to give results between 20 and $35 \mathrm{sec}$. Results are given as units of heparin per millilitre of blood and are available in approximately $5 \mathrm{~min}$. after receipt of the specimen. Heparin concentration of not less than $0.01 \mathrm{u}$. in $0.05 \mathrm{ml}$. can be determined satisfactorily. The results have an error of $\pm 0.2 \mathrm{u}$. heparin per $\mathrm{ml}$. This is acceptable during the operation. In the postoperative period, however, greater accuracy is required to enable complete neutralization of circulating heparin. This can be obtained with the following technique. Oxalated blood is centrifuged and to $0.2 \mathrm{ml}$.

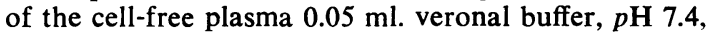
ionic strength 0.15 , and $0.1 \mathrm{ml}$. thrombin are added. The sensitivity of the test is thus increased to $0.05 \mathrm{u}$. heparin $/ \mathrm{ml}$. plasma, i.e., approximately $0.025 \mathrm{u} . / \mathrm{ml}$. blood. With the latter test it is necessary to establish whether the thrombin clotting time is influenced by other factors in addition to heparin; fibrinogen in particular has to be considered. It is therefore necessary to carry out an additional test by adding $0.05 \mathrm{ml}$. of a solution of protamine sulphate in veronal buffer instead of $0.05 \mathrm{ml}$. veronal buffer. If the proper amount of protamine is added heparin is neutralized and the clotting time is the same as is obtained after addition of veronal buffer to heparinfree plasma. A prolongation of the thrombin clotting time indicates fibrinogen deficiency. This more elaborate testing for heparin requires approximately 25 min.

Preparation of Heparin Solutions.-Heparin is available commercially as a sodium compound either 
in the solid form or in solution. Some firms add phenolic preservatives to their product. For certain experiments it was desired to use heparin solution without a preservative. Although Torpy (1959) states that heparin may be sterilized by autoclaving at $110^{\circ}$ for $30 \mathrm{~min}$., our experience indicates that careful attention to $\mathrm{pH}$ of the heparin solution is essential for preservation of heparin in this procedure. The following experiment may be cited as a warning.

Three solutions each containing $2.5 \mathrm{~g}$. dextrose and $2,000 \mathrm{u}$. heparin in $52 \mathrm{ml}$. water were prepared. The pH was 5.6. One solution was kept at room temperature, the second was sterilized at $110^{\circ} \mathrm{C}$. for $30 \mathrm{~min}$. and then cooled to room temperature, and the third was passed through a Seitz filter. To each solution was added $450 \mathrm{ml}$. $0.154 \mathrm{M} \mathrm{NaCl}$.

The heat-sterilized solution now contained only $500 \mathrm{u}$. heparin, whereas the control solution and the filtered solution still contained 2,000 u. heparin.

\section{Relation Between Heparin Concentration and Whole Blood Clotting Time}

Heparin is used as an anticoagulant both in the donor's and the patient's blood. In the former case, however, non-coagulability has to be maintained for a much longer time than in the patient's blood. As the minimal amount of heparin required to produce non-coagulability in a patient's circulation during the operation has not been established, heparin concentrations and whole blood clotting times were determined on the blood of patients who received heparinized blood during and after bypass. The results are given in Fig. 1 .

From the results in Fig. 1 it is apparent that there is a very poor correlation between the heparin concentration and the whole blood clotting time in blood specimens taken during surgery. This is probably due to the fact that the blood specimens are taken under unfavourable conditions, either from the venous end of the pump or

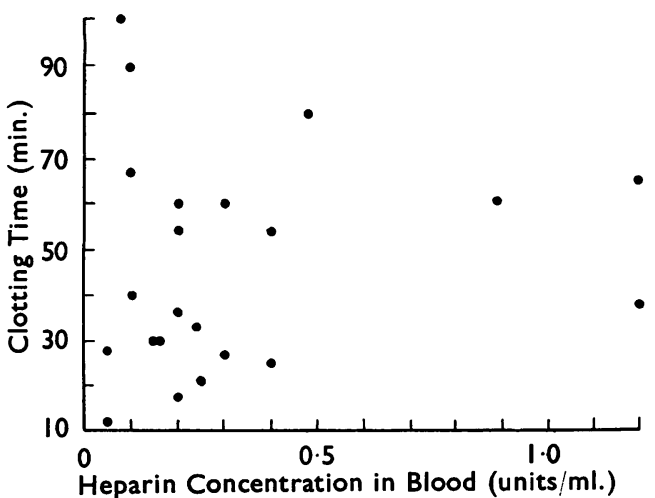

FIG. 1.-Clotting times and heparin concentrations of blood of patients undergoing open-heart surgery. from indwelling catheters. Further, the blood specimens often show haemolysis, of varying degree, and perhaps contain thromboplastin released from the tissues during the operation. All these factors will tend to shorten the clotting time. Nevertheless the results in Fig. 1 indicate that in the presence of between 0.05 and $1.2 \mathrm{u}$. heparin $/ \mathrm{ml}$. blood clotting could occur in measurable time and therefore a higher concentration of heparin should be maintained in the circulation in order to render blood non-coagulable. In addition, an experiment was carried out in which $0.1 \mathrm{ml}$. brain extract as a source of potent thromboplastin and $0.1 \mathrm{ml} .0 .01 \mathrm{M}$ calcium chloride were added to $0.1 \mathrm{ml}$. heparinized plasma obtained from blood which contained $3 \mathrm{u}$. heparin per $\mathrm{ml}$. No clotting occurred in $2 \mathrm{~min}$., whereas heparin-free plasma clotted in $14 \mathrm{sec}$.

Since during the operation potent thromboplastic materials are liberated into the circulating blood it seems that at least $2 \mathrm{u}$. heparin $/ \mathrm{ml}$. blood would be required to ensure non-coagulability.

With regard to donor blood the following heparin activities were found approximately 16 hours after the addition of $4 \mathrm{u}$. heparin $/ \mathrm{ml}$. blood during collection (Table I). It is seen from Table I

TABLE I

HEPARIN ACTIVITY OF DONOR BLOOD HEPARINIZED WITH 4 u. $/ \mathrm{ml}$

\begin{tabular}{c|c}
\hline Specimen No.* & Heparin Found (units $/ \mathrm{ml}$. ) \\
\hline 4,516 & $2 \cdot 8$ \\
4,517 & $3 \cdot 0$ \\
4,513 & $3 \cdot 0$ \\
X & $2 \cdot 8$ \\
932 & $2 \cdot 4$ \\
935 & $2 \cdot 3$ \\
939 & $3 \cdot 1$
\end{tabular}

* The blood specimens were collected on the afiernoon before use, kept at $6^{\circ} \mathrm{C}$. till 7 a.m. next morning and warmed to $37^{\circ} \mathrm{C}$. ; $2,000 \mathrm{u}$. solution was added during collection to each $500 \mathrm{ml}$. blood.

that the detected heparin activity was in the average $2.8 \mathrm{u}$. $/ \mathrm{ml}$., representing a recovery of $70 \%$ of the added heparin.

Heparinized donor blood could be kept for at least another eight hours at $6^{\circ} \mathrm{C}$. without further loss of heparin activity. Quite frequently small clots were present in the donor blood which at times interfered with the inflow to the pump oxygenator, but analysis for factor VIII (antihaemophilic factor) and a platelet count did not indicate significant changes in the blood composition.

Immediately before the bypass the patients were given intravenously 150-200 u. heparin per kg. of body weight. The heparin concentration in blood 
during extracorporeal circulation was calculated from the volume of heparinized donor blood, which was assumed to contain $2.8 \mathrm{u}$. heparin $/ \mathrm{ml}$. (see Table I), the calculated blood volume of the patient and the amount of heparin given to the patient immediately before the bypass. The blood volume of the patient in litres was assumed to be $1 / 13$ of the body weight in kilograms. From these data it was calculated that the circulating blood contained approximately $2.5 \mathrm{u} . / \mathrm{ml}$. blood during $30 \mathrm{~min}$. on bypass. A comparison of the calculated figure and the observed results is given in Fig. 2.

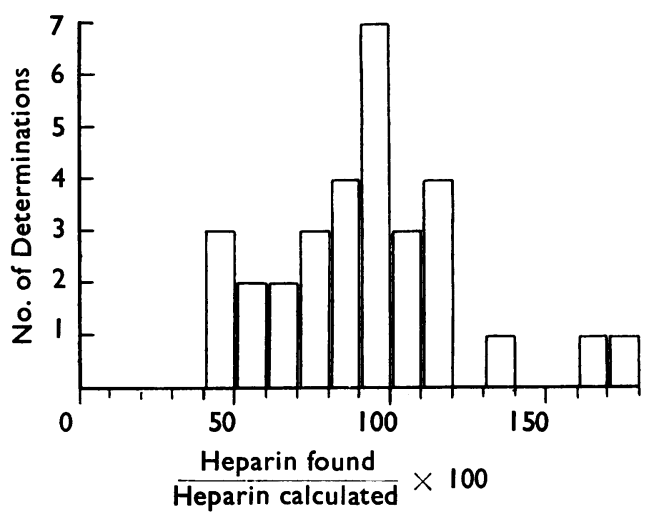

FIG. 2.- Ratios of found to calculated heparin concentrations in blood of patients during open-heart surgery. (For methods of determination and calculation see text.)

From these results it is seen that in 18 out of 31 cases the concentration was $2-3 \mathrm{u} . / \mathrm{ml}$. blood, i.e., $80-120 \%$ of the calculated concentration. In three cases the found value was excessive (3-4.5 u. $/ \mathrm{ml}$., i.e., $120-180 \%$ of calculated) and in 10 cases this was unexpectedly low $(1-2 \mathrm{u} . / \mathrm{ml}$., i.e., $40-80 \%$ of calculated). It is possible that these 13 results were partly due to technical errors and partly due to errors in the calculated heparin concentration. The observed heparin concentration was maintained in each patient for approximately $30 \mathrm{~min}$. if it was not reduced by injection of protamine sulphate.

In one case $7.7 \mathrm{u}$. of heparin was found per millilitre of circulating blood. Assays performed later on three bottles of donors' blood showed them to contain 10-14 u. heparin $/ \mathrm{ml}$. Inquiry established that by mistake instead of $4 \mathrm{u}$., $20 \mathrm{u}$. of heparin $/ \mathrm{ml}$. had been added during blood collection. This patient did not show any signs of untoward effects due to excess of heparin, and, except that larger amounts than usual of protamine were required, recovery was uneventful (Fig. 4).
If the bypass was longer than $30 \mathrm{~min}$., further injections of heparin to produce $2 \mathrm{u}$. $/ \mathrm{ml}$. blood were given.

\section{Removal of Heparin by Protamine}

As soon as the bypass was concluded the patient received protamine sulphate intravenously and this had an immediate neutralizing effect on heparin. However, free protamine has undesirable side-effects and the amount present in the circulation should therefore not be excessive.

The required amount of protamine was determined by adding known amounts of heparin to normal human oxalated plasma and determining the amount of protamine which was required to give the same clotting time as in the absence of heparin. This was considered to indicate the optimum amount of protamine to be administered to the patient. In three experiments $2.1 \pm 0.5 \mu \mathrm{g}$. of protamine sulphate was required to neutralize the effect of $1 \mu \mathrm{g}$. $(0.1 \mathrm{u}$.) of heparin.

Heparin determinations were carried out between 30 and $60 \mathrm{~min}$. after intravenous administration of protamine sulphate to patients at the completion of the bypass. The following results, calculated per $\mu \mathrm{g}$. of heparin. were obtained.

Injection of 1 to $1.5 \mu \mathrm{g}$. protamine sulphate (per $\mu \mathrm{g}$. heparin) resulted in heparin levels averaging $0.8 \mathrm{u} . / \mathrm{ml}$. blood (variation $0.1-1.65$ ) in eight cases. Injection of 1.6 to $1.9 \mu \mathrm{g}$. protamine sulphate resulted in heparin levels averaging $0.5 \mathrm{u} . / \mathrm{ml}$. (variation 0.1-1.2) in eight cases, and injection of 2 to $2.7 \mu \mathrm{g}$. protamine sulphate resulted in 0 to $0.1 \mathrm{u}$. heparin $/ \mathrm{ml}$. in three cases. From these results it appears that in agreement with the experiments in vitro approximately $2.5 \mu \mathrm{g}$. of protamine sulphate was required to inactivate $1 \mu \mathrm{g}$. (0.1 u.) of heparin in the circulation. It is therefore suggested that $4 \mathrm{mg}$. protamine sulphate per kilogram of body weight will neutralize heparin after bypass is concluded, assuming a heparin concentration of approximately $2 \mathrm{u}$./ $\mathrm{ml}$. blood.

In 14 out of 29 cases, only one protamine sulphate injection was given. This was sufficient to neutralize heparin within approximately $30 \mathrm{~min}$. in seven cases. In the remaining seven cases heparin was still present at this time, but it disappeared without further treatment and no reappearance of heparin was detected.

Occasionally heparin reappeared in the patient's blood after about one hour and further protamine sulphate injections were necessary. This reappearance of heparin in the circulation is probably partly due to a breakdown of the 
TABLE II

HEPARIN REAPPEARANCE IN PLASMA CONTAINING HEPARIN-PROTAMINE COMPLEX (EXPERIMENT IN VITRO)

\begin{tabular}{|c|c|c|c|c|c|}
\hline & & \multicolumn{2}{|c|}{$\begin{array}{l}\text { Volume Used in } \\
\text { Determination of } \\
\text { Thrombin Clot- } \\
\text { ting Time (ml.) }\end{array}$} & \multicolumn{2}{|c|}{$\begin{array}{l}\text { Thrombin } \\
\text { Clotting } \\
\text { Time* (sec.) }\end{array}$} \\
\hline & & $\begin{array}{l}\text { Normal } \\
\text { Human } \\
\text { Plasma }\end{array}$ & $\begin{array}{l}\text { Test } \\
\text { Prepa- } \\
\text { ration }\end{array}$ & $\begin{array}{l}\text { Imme- } \\
\text { diately } \\
\text { After } \\
\text { Prepa- } \\
\text { ration }\end{array}$ & $\begin{array}{l}\text { After } \\
90 \mathrm{~min} . \\
\text { at } 37^{\circ} \mathrm{C} .\end{array}$ \\
\hline $\begin{array}{l}\text { Test } \\
\text { Prepa- } \\
\text { rations }\end{array}$ & $\begin{array}{l}\text { A. Normal human } \\
\text { plasma } \\
\text { B. A, with } 4 \text { u. hepa- } \\
\text { rin and } 80 \mu \mathrm{g} \text {. } \\
\text { protamine sulph- } \\
\text { ate added } / \mathrm{ml} \text {. } \\
\text { C. A, with } 0 \cdot 2 \mathrm{u} \text {. } \\
\text { heparin added'ml. } \\
\text { D. B, incubated } 90 \\
\text { min. at } 37^{\circ} \text { C., } \\
\text { then } 20 \mu \text { g. prot- } \\
\text { amine sulphate } \\
\text { added } / \mathrm{ml} \text {. }\end{array}$ & $\begin{array}{l}0.2 \\
- \\
0.19 \\
0.15\end{array}$ & $\begin{array}{l}0.01 \\
0.05\end{array}$ & - & $\begin{array}{r}21 \\
>180 \\
27 \\
-\end{array}$ \\
\hline
\end{tabular}

* Thrombin clotting times were determined with a total of $0.2 \mathrm{ml}$ plasma, made up as indicated in Table, $0.05 \mathrm{ml}$. veronal buffer, $p \mathrm{H}$ $7 \cdot 4$, iontic strength $0 \cdot 15,0.05 \mathrm{ml} ., 0.154 \mathrm{M} \mathrm{NaCl}$, and $0.1 \mathrm{ml}$. thrombin at $37^{\circ} \mathrm{C}$.

heparin-protamine complex by a plasma enzyme. This was verified by experiments in vitro. Table II shows the results of one such experiment in which plasma contained $4 \mathrm{u}$. heparin $/ \mathrm{ml}$. as bound heparin in the protamine complex and no free heparin immediately after preparation. After $90 \mathrm{~min}$. incubation at $37^{\circ} \mathrm{C}$., $1 \mathrm{u}$. of free heparin/ $\mathrm{ml}$. plasma had been released from the protamineheparin complex.

The reappearance of heparin after administration of protamine can of course cause bleeding, and since there are several possible causes for haemorrhages in the post-operative period it may be of value to determine whether or not heparin is one of the causes. This can be illustrated by

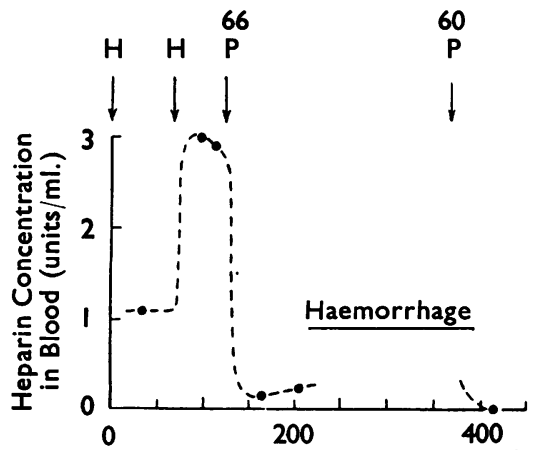

Time after Heparinization of Patient (min.)

FIG. 3.-Heparin concentration in blood of patient (G.B.) undergoing open-heart surgery. $\mathrm{H}=$ intravenous injection of heparin. $\mathbf{P}=$-intravenous injection of protamine sulphate (mg.). the following instance. As is seen from Fig. 3, $38 \mathrm{~min}$. after the first protamine injection the heparin concentration was $0.16 \mathrm{u} . / \mathrm{ml}$. blood; $40 \mathrm{~min}$. later it was $0.22 \mathrm{u}$. and the whole blood clotting time was $35 \mathrm{~min}$. (normal 9-20 min.). Bleeding into the chest occurred and a second protamine injection brought the heparin level down to zero and the haemorrhage stopped.

The following case shows the value of postoperative heparin assays and coagulation tests in assisting to establish the reason for abnormal bleeding.

A patient (W. D. V.), 20 years of age, $50 \mathrm{~kg}$. weight, showed pre-operatively a slight defect in the thromboplastin generation test which could have been due to either a mild P.T.A. deficiency or a Hageman factor deficiency. His blood contained $2.4 \mathrm{u}$. of heparin $/ \mathrm{ml}$. at the time bypass was concluded. He received $20 \mathrm{ml}$. of a protamine sulphate solution containing $1 \mathrm{~g}$./ $100 \mathrm{ml}$. intravenously and $33 \mathrm{~min}$. later no heparin was detected in his blood. A haemorrhage into the chest occurred, but heparin was still not detectable one hour later. It was concluded that the haemorrhage was not due to heparin nor to a coagulation abnormality. The situation was resolved when a haemorrhage from the incision in the right ventricle was found.

An illustration that even excessive heparinization did not produce any apparent harm to the patient and could be successfully counteracted with four injections of protamine is given in Fig. 4. (Details of heparinization of this patient are given on previous page.) Fig. 4 includes data on heparin activity as well as whole blood clotting times, which indicates that at times even low concentrations of heparin $(0.25 \mathrm{u} / / \mathrm{ml}$. blood $)$ can cause

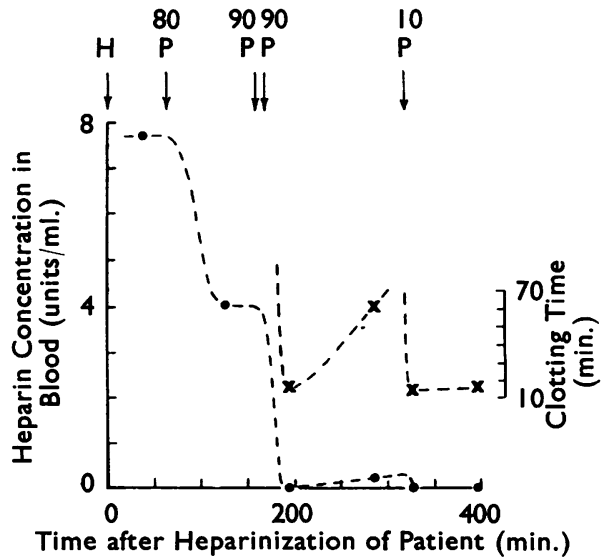

FIG. 4.-Heparin concentration in blood of patient (E.M.) undergoing open-heart surgery (curve ---$)$ ). The curve $(x---)$ on the right-hand side shows blood clotting times. 
considerable prolongation of the whole blood clotting time (60 min.).

\section{Determination of Blood Coagulation factors in Post-operative Period}

In a number of instances several blood coagulation factors were determined after the administration of protamine sulphate. However, the results were only reliable if the heparin concentration was lower than $0.1 \mathrm{u}$. heparin $/ \mathrm{ml}$. plasma. Higher heparin concentrations masked all the reactions studied and are therefore not reported.

In the 10 cases investigated one-stage prothrombin tests were a few seconds longer than the normal controls. In a number of cases in which the one-stage prothrombin times were prolonged there was a deficiency of one or more serum factors.

Prothrombin assays were always lower than normal. Reduction to 50 to $60 \%$ of the normal level occurred in eight cases and to 70 to $90 \%$ of normal in six cases.

There appeared to be no significant reduction in factor $\mathrm{V}$ activity.

In eight cases in which thrombin generation tests were performed, two were normal, four were slightly abnormal, and two significantly abnormal. Thromboplastin generation tests were carried out on 10 cases; seven were normal or only slightly abnormal and three differed appreciably from normal.

Fibrinogen concentration was either determined directly by isolation of fibrin or indirectly by the thrombin clotting time. In no case was a significant reduction observed. The clots in the tubes in which whole blood clotting times were determined were observed for approximately 14 hours at $37^{\circ} \mathrm{C}$. In cases where heparin was present poor clot retraction was noticed, but in specimens which were free of heparin clot retraction was not impaired. Lysis of the fibrin clot was not observed in any case. Fibrinolysis was positive in one case in which diluted plasma was used for the test.

\section{Platelet Preservation After Extracorporeal Circulation}

At first the Lillehei-De Wall bubble oxygenator was employed in the extracorporeal circulation, but later a disc oxygenator of the Kay-Cross type was used. In the Lillehei-De Wall machine it is necessary to apply a defoaming agent, and a silicone grease is usually used for this purpose. In order to show whether the omission of silicone coating had any deleterious effect on blood platelets, counts were carried out on heparinized donor blood and on the patient's blood before and after extracorporeal circulation.

As can be seen from Table III the platelet numbers were practically unaltered in heparinized blood which was in contact with uncoated glass and stainless steel surfaces.

TABLE III

BLOOD PLATELET LEVELS IN OPEN-HEART SURGERY (KAY-CROSS DISC OXYGENATOR)

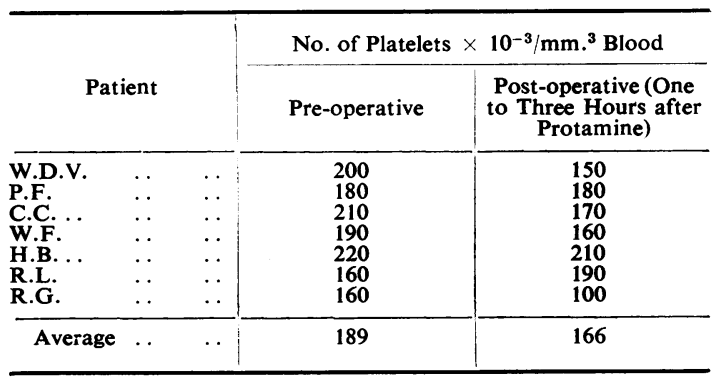

\section{Discussion}

The determination of blood clotting factors in the pre-operative period is advisable since the patients who have to undergo surgery are mostly young; because of their disability they lead a sheltered life, so that even a serious haemorrhagic tendency may have remained unnoticed, but may become manifest in the post-operative period. The large amounts of fresh heparinized normal blood and also citrated blood which are employed during and after the operation will mask a haemorrhagic tendency, but the turnover rate of several plasma factors involved in blood coagulation is not more than one or two days.

Among 50 patients three had a deficiency of factor VII. However, the degree of deficiency (25-50\% of normal level) was not severe enough to produce haemorrhages and the surgeon found post-operative bleeding not excessive.

One patient had a severe coagulation abnormality due to absence of Hageman factor. He also had the Ehlers-Danlos syndrome. It is known that persons with the Hageman trait, despite laboratory evidence of a severe coagulation defect, do not bleed excessively even after severe trauma; but in patients with the Ehlers-Danlos syndrome haemorrhages may occur because of vascular fragility. The above patient at no time bled excessively.

Other workers have reported coagulation abnormalities in cardiac patients (Favre-Gilly, $\stackrel{\mathbb{Q}}{\varrho}$ Bret, and Borel-Milhet, 1951 ; Hartmann, 1952 ; 
De Wall, Warden, Gott, Read, Varco, and Lillehei; 1956 ; van Creveld, 1958 ; Von Kaulla and Swan, 1958).

In a number of instances it was found that the concentration of one or more plasma components of the blood clotting system was reduced after neutralization of heparin by protamine. However, in no case was the reduction sufficiently great to be a likely cause of a haemorrhagic tendency. The laboratory findings agreed with the clinical observations.

In a bubble type oxygenator it is necessary to apply a defoaming agent; usually a silicone is employed. This has also been recommended in a disc oxygenator, it is believed for platelet protection. However, in view of the fact that the silicone films on glass and metal surfaces are partly removed and enter the patient's circulation, silicone coating should be avoided because the high polymer silicones may produce a foreign body reaction. Indeed, Penry, Cordell, Johnston, and Netsky (1959) have reported the occurrence of cerebral embolism in dogs after an injection of antifoam A, a methyl polysiloxane resin, while Yates, Cassie, Dark, Jack, and Riddell (1959) have detected antifoam emboli in dogs after perfusion with a De Wall pattern bubble oxygenator coated with antifoam A. Apart from these observations, the omission of silicone seems to be justified as is seen from the determination of platelet number in the immediate post-protamine period. In the average no significant change of the platelet numbers was detected, although we are informed that by the third post-operative day in all cases the platelets had dropped significantly to a minimum level which averaged $45 \%$ of the original count (R. A. Hayes, unpublished observations). This is in general agreement with observations made by Crafoord, Norberg, and Senning (1957) and by De Wall, Long, Gemmill, and Lillehei (1959).

It would appear that coating the oxygenator with silicone is undesirable because of the danger of deposition of silicone in the patient's body and unnecessary for the prevention of platelet loss. However, the use of non-siliconed apparatus may not always be practicable because of the collection of gas bubbles on the uncoated surfaces, especially at high flow rates, with consequent danger of air emboli. The answer to this problem probably lies in the use of a solid, non-wettable material either as a coating for glass and metal components or as the actual material from which the apparatus is fabricated.

There is disagreement in the literature on the quantity of protamine required to neutralize a given quantity of heparin. Under our experi- mental conditions a protamine: heparin ratio of approximately $2.5: 1$ was found for complete neutralization, both in vivo and in vitro. The complete neutralization of heparin is important in preventing abnormal post-operative bleeding.

The reappearance of heparin after its neutralization was observed in several instances and it is believed to have been responsible in some cases for haemorrhage because repeated protamine administrations stopped excessive bleeding. This so-called " heparin rebound" has been reported by Effler, Kolff, Groves, and Sones (1956). Reappearance of heparin can be explained partly by the liberation of heparin from the heparinprotamine complex by a plasma enzyme.

Our experience indicated that a heparin concentration of approximately $2.5 \mathrm{u} . / \mathrm{ml}$. is adequate to maintain non-coagulability and that a much higher concentration did not seem to offer any advantage.

We have observed a loss of approximately $30 \%$ of heparin during storage of heparinized blood at $6^{\circ} \mathrm{C}$. for approximately 16 hours.

\section{SUMMARY}

A technique for determination of heparin in whole blood which can be carried out in a few minutes is described.

Precautions for the preparation of heparin solutions are given.

A loss of heparin activity on storage of heparinized blood is reported.

Heparin concentration in patients' blood was determined during and after extracorporeal circulation for open-heart surgery.

The weight of protamine required to neutralize a given weight of heparin was found to be approximately $2-2.5$ times the weight of heparin, in vivo and in vitro.

In occasional cases reappearance of heparin in the patient's blood after neutralization by protamine was observed.

The value of determining blood coagulation factors in cardiac patients before and after openheart operations is indicated.

The results of pre- and post-operative coagulation tests are presented and discussed.

It is shown that human blood platelets are preserved in heparinized blood in contact with non-siliconized glass and stainless steel surfaces.

This work was carried out in close collaboration with the honorary thoracic surgeon of the Alfred Hospital, Melbourne, Mr. K. N. Morris, who, with his 
assistants, provided the blood specimens. Mrs. J. Bathie provided excellent technical assistance in the performance of laboratory tests.

\section{REFERENCES}

Crafoord, C., Norberg, B., and Senning, A. (1957). Acta chirurg. scand., 112, 220.

Creveld, S. van (1958). Ann. paediat. (Basel), 190, 342.

De Wall, R. A., Long, D. M., Gemmill, S. J., and Lillehei, C. W. (1959). J. thorac. Surg., 37, 325

Warden, H. E., Gott, V. L., Read, R. C., Varco, R. L., and Lillehei, C. W. (1956). Ibid., 32, 591.
Effler, D. B., Kolff, W. J., Groves, L. K., and Sones, F. M.. Jr. (1956) Ibid., 32, 620 .

Fantl, P. (1954). Aust. J. exp. Biol.med. Sci., 32, 853.

- and Ward, H. A. (1960). J. Physiol. (Lond.), 150, 607.

Favre-Gilly, J., Bret, J., and Borel-Milhet, J. (1951). Sang, 22, 278.

Hartmann, R. C. (1952). Bull. Johns Hopk. Hosp., 91, 49.

Hayes, R. A. Unpublished observations.

Penry, J. K., Cordell, A. R., Johnston, F. R., and Netsky, M. G. (1959). J. thorac. Surg., 37, 342.

Torpy, D. C. (1959). In Data for Biochemical Research, p, 166, ed. R. M. C. Dawson, D. C. Elliott, W. H. Elliott, and K. M. Jones. Clarendon Press, Oxford.

Von Kaulla, K. N., and Swan, H. (1958). J. thorac. Surg., 36, 519.

Yates, P. O., Cassie, A. B., Dark, J. F., Jack, G. D., and Riddell, A. G. (1959). Lancet, 1, 130. 